\title{
Relationship between Nutritional Status and School Achievement of Elementary School Students Aged 10-13 Years
}

\author{
Christy Venada, ${ }^{1}$ Felicia Kurniawan, ${ }^{2}$ Isadora Gracia, ${ }^{3}$ Yunisa Astiarani ${ }^{2}$ \\ ${ }^{1}$ School of Medicine and Health Sciences, Atma Jaya Catholic University of Indonesia, Indonesia, \\ ${ }^{2}$ Department of Public Health and Nutrition, School of Medicine and Health Sciences, Atma Jaya \\ Catholic University of Indonesia, Indonesia, ${ }^{3}$ Department of Dental Medicine, School of Medicine \\ and Health Sciences, Atma Jaya Catholic University of Indonesia, Indonesia
}

\begin{abstract}
Background: School achievement is a crucial element in determining the students' success. Nutritional status is one of the factors that influence school achievements. This study aimed to analyze the relationship between nutritional status and school achievements among elementary school students.

Methods: The cross-sectional analytic observation was conducted during April-November 2019 using a total sampling approach. Four elementary schools in Penjaringan, North Jakarta were chosen and students aged $>10$ years were selected. The data collected were gender, age, weight, height, and midterm test scores recorded in the school report, including mathematics, science, and Indonesian language. The nutritional status was assessed by body mass index (BMI) and classified upon Permenkes 2 Tahun 2020, which were deficient, sufficient, and overnutrition. Assessment of school achievement based on midterm test scores, categorized according to the 2016 Assessment Guidelines for Elementary Schools (Panduan Penilaian untuk Sekolah Dasar), into three classifications of good, fair, and poor. Data were analyzed using Chi-square.

Results: Of the 436 students, $21.8 \%(n=95)$ of students were considered good, $28.2 \%(n=123)$ were fair, and $50 \%(n=218)$ were poor. The nutrition level was deficient in $9.6 \%(n=42)$ students, whereas $54.8 \%(n=239)$ students had sufficient nutrition, and 35.6\% ( $n=155)$ students had overnutrition. Bivariate analysis test showed a statistically insignificant relationship between nutritional status and school achievement ( $\mathrm{p}>0.05)$.

Conclusion: This study indicates that nutritional status does not affect school achievement. Further study is needed to determine other factors such as health, intelligence, anxiety, motivation, family, and living environment that may influence school achievement.
\end{abstract}

Keywords: Elementary school students, nutritional status, school achievement

\section{Introduction}

When one talks about education, school achievement is something that one cannot forget as it stands as a benchmark in determining how successful the students are. In 2018, the Programme for International Student Assessment (PISA) has conducted a study on gauging Indonesian students' reading competence, mathematics, and science. Compared to global statistics, Indonesia currently ranks at the bottom with stagnant growth in the recent 15 years. $^{1}$ School achievement is affected by many factors such as nutritional status, intelligence, self-esteem, family support, and others. ${ }^{2}$

Nutritional status is one of the important factors that affect the school achievement of a student in elementary school. The better nutritional status, the better school achievement of student. ${ }^{3}$ Based on the 2018 of Basic Health Research (Riset Kesehatan Dasar, RISKESDAS) data, Daerah Khusus Ibukota (DKI) Jakarta ranks second in the prevalence of malnourished children aged 5-12 years from all provinces. ${ }^{4}$ On top of that, several studies have shown that under nutrition and over nutrition significantly affect school

Correspondence: Christy Venada, School of Medicine and Health Sciences, Atma Jaya Catholic University of Indonesia, Jalan Pluit Raya No. 2, North Jakarta, Indonesia, E-mail: christyvenada@gmail.com 
achievement. Well-nourished children may also have great school achievements. ${ }^{5,6}$

The high prevalence of under nutrition and over nutrition in DKI Jakarta is underpinned by the absence of research that states the relationship between nutritional status and school achievement of elementary school students, especially in North Jakarta. Nutritional status can have a long-term impact on daily activities and achievement. Therefore, this study aimed to determine the relationship between nutritional status and school achievement in children aged ten years and over in North Jakarta.

\section{Methods}

This research was a cross-sectional, analytic observational study, which was conducted in four schools at Penjaringan, North Jakarta, from April to November 2019, including two public and two private schools. A total sampling approach was applied to 652 students aged over ten years from two government owned primary schools and two private schools. Exclusion criteria were students who suffered from Attention-deficit/hyperactivity disorder (ADHD), mental retardation, or quadriplegic, and students who did not attend school. This data were assessed with data on students' health conditions from the principal.

Before gathering data, informed consent was obtained from the principal. Ethical clearance was obtained from the chairman of the ethics committee of the Faculty of Medicine at the Atma Jaya Catholic University of Indonesia with the number 17/06/KEPFKUJAJ/2020.

The weight and height of the students were measured three times with Tanita sclaes and a microtome to calculate body mass index (BMI). The BMI was then classified according to the Regulation of the Minister of Health, the Republic of Indonesia (Peraturan Menteri Kesehatan RI, Permenkes RI) no 2 year 2020, which stipulated undernutrition, sufficient, and overnutrition. BMI that was below -2 standard deviations (SD) was categorized as undernourished. BMI between -2 SD and +1 SD was categorized as sufficient nutrition. BMI above +1 SD was categorized into overnutrition. ${ }^{7}$ The mid-term test scores for the subjects tested on the elementary school national exams, including mathematics, science, and Indonesian, were taken from their mid-semester school report cards. Scores were classified based on the 2016 Assessment Guide for Elementary Schools (Panduan Penilaian untuk Sekolah Dasar) which referred to the class intervals of each minimum score required (kriteria ketuntasan minimal-KKM) by the school, to determine good, fair, and poor. ${ }^{8}$

The research data were analyzed with statistical software for data science (STATA) version 16 for Windows, where the data were

Table 1 Characteristic of Students from Four Elementary Schools in North Jakarta

\begin{tabular}{|c|c|c|}
\hline Variable & $\mathbf{n}$ & $\%$ \\
\hline \multicolumn{3}{|l|}{ Gender } \\
\hline Male & 240 & 55.1 \\
\hline Female & 196 & 44.9 \\
\hline \multicolumn{3}{|l|}{ Age } \\
\hline 10 years & 226 & 51.8 \\
\hline 11 years & 137 & 31.4 \\
\hline 12 years & 68 & 15.6 \\
\hline 13 years & 5 & 1.2 \\
\hline \multicolumn{3}{|l|}{ Education level } \\
\hline $4^{\text {th }}$ grade & 94 & 21.5 \\
\hline $5^{\text {th }}$ grade & 156 & 35.8 \\
\hline $6^{\text {th }}$ grade & 186 & 42.7 \\
\hline \multicolumn{3}{|l|}{ Elementary school } \\
\hline SDN 08 & 159 & 36.5 \\
\hline SDN 10 & 148 & 33.9 \\
\hline Stella Maris & 47 & 10.8 \\
\hline Westin & 82 & 18.8 \\
\hline
\end{tabular}

Note: SDN= sekolah dasar negeri (public elementary school) 
Table 2 Relationship between Nutritional Status and School Achievement of Elementary School Students Aged 10-13 Year Old

\begin{tabular}{|c|c|c|c|c|c|c|c|c|}
\hline \multirow{3}{*}{ Nutritional Status } & \multicolumn{6}{|c|}{ School Achievement } & \multirow{2}{*}{\multicolumn{2}{|c|}{ Total }} \\
\hline & \multicolumn{2}{|c|}{ Good } & \multicolumn{2}{|c|}{ Fair } & \multicolumn{2}{|c|}{ Poor } & & \\
\hline & $\mathbf{n}$ & $\%$ & $\mathbf{n}$ & $\%$ & $\mathbf{n}$ & $\%$ & $\mathbf{n}$ & $\%$ \\
\hline Deficient & 10 & 23.8 & 13 & 31 & 19 & 45.2 & 42 & 9.6 \\
\hline Sufficient & 59 & 24.7 & 65 & 27.2 & 115 & 48.1 & 239 & 54.8 \\
\hline Over & 26 & 16.8 & 45 & 29 & 84 & 54.2 & 155 & 35.6 \\
\hline Total & 95 & 21.8 & 123 & 28.2 & 218 & 50 & 436 & 100 \\
\hline
\end{tabular}

Note: $\mathrm{p}=0.416$

divided into univariate and bivariate data. Univariate data showed the respondents distribution based on characteristics (gender, age, class), school achievement, and nutritional status. In contrast, bivariate data showed the respondents distribution based on the relationship between nutritional status and school achievement. Chi-square was used to analyze bivariate data. The data were presented in tables.

\section{Results}

Out of 652 students from four schools, only 436 students qualified as respondents in this study. The number of boys was slightly higher $(55.1 \%)$ compared to girls (Table 1 ). In terms of school achievement, most of the respondents had a "Poor" predicate compared to "Good" and "Fair" students. Meanwhile, the prevalence of respondents with sufficient nutritional status was $54.8 \%$ and overnutrition and deficient nutritional status were $35.5 \%$ and $9.6 \%$ (Table 2).

Bivariate analysis of the relationship between nutritional status and school achievement resulted in $p=0.416 \quad(p>0.05)$, indicating that there was no relationship between nutritional status and school achievement (Table 2).

\section{Discussion}

In RISKESDAS 2018, the prevalence of nutritional status of children aged 5-12 years who have sufficient nutrition is projected at $62.9 \%$ in DKI Jakarta, ${ }^{4}$ and our study shows a slightly lower number (54.8\%). Having sufficient nutrition means the food is in accordance with the daily needs of the body. Foods that contains adequate nutritional intake can meet the children's nutritional needs and affect their nutritional status. ${ }^{9}$ Children with good or normal nutritional status will be able to learn more, create healthier and more productive adults, ${ }^{10}$ resulting in a better future generation of the nation.

Overnutrition status in this study is classified as obese. Based on the 2018 RISKESDAS data, the prevalence of nutritional status (BMI by age) in children aged 5-12 years and adolescents aged 13-15 years in DKI Jakarta Province showed approximately $29.2 \%$ and $25.1 \%$, respectively, slightly lower than the prevalence of overnutrition status in this study, which is $35.5 \%$. As for the undernutrition status in this study or otherwise classified as malnourished, our study shows that the deficiency status is $9.6 \%$, slightly higher than the prevalence of deficiency nutritional status in children aged 5-12 years and adolescents aged $13-15$ years, which are $7.9 \%$ and $8.1 \%$, respectively. ${ }^{4}$

A study has shown that there are more respondents with low school achievement in 3 school subjects, namely: Indonesian, Mathematics, and Science. 9,11 The low school achievement proves that the learning efforts of elementary students are still considered poor. Several factors might make someone excel in school: learning motivation, family support, intelligence, talents, interests, and others.

The relationship between nutritional status and school achievement, which is not significant in this study, is completely different from the study conducted in Yogyakarta, ${ }^{12}$ that has shown a significant result. This study explains that if the child's nutritional status improves, the school achievement will also be better. Thus, the nutritional status is one of the critical factors that directly contribute to the quality of child growth and development. Consuming good and balanced nutrition may lead to better grades in school. A better score is an indicator that a child's education at school is also good. Carbohydrates, protein, 
iron, and other nutrients play an important role in the thought processes, common sense, and concentration. Having these 3 abilities naturally results in better learning efficiency as well. On the other hand, malnourished children would easily get sleepy and lack energy to participate in school activities, leading to declining school achievement. ${ }^{12}$

The results of this study contradict another study in Kediri, ${ }^{13}$ which shows a relationship between overnutrition and children's school achievement. The study implies that obese children tend to have poor health. Overnutrition can cause a decrease in children's activity and creativity, causing a sense of laziness, Therefore, it might decrease children's level of intelligence. One of the causes of obesity is increased fat deposits that can block blood flow to the brain. The blocked blood flow causes a lack of oxygen levels in the brain, causing concentration problems. Concentration problems greatly affect the child's learning process so that it declines at school.

Study in Pekanbaru ${ }^{9}$ has found the same results as this study, showing no relationship between nutritional status and school achievement in students $(p=0.771)$. School achievement is not only influenced by nutritional status but is multifactorial. In general, students' school achievement can be influenced by factors that come from internal factors and external factors. Opinions about school achievement are a multifactorial variable, supported by other studies, suggesting that there are many other factors that affect school achievement, such as physical health or physiology, genetics, child psychology, intelligence, talents, interests, motivation in the family environment, school environment, and community environment around children. ${ }^{14}$

Nutritional status is not only determined by anthropometric measurements or BMI. ${ }^{15}$ Nutritional status can be determined biochemically, specifically by blood examinations in the laboratory, for example iron deficiency anemia which can cause a decrease in concentration, intelligence, and school achievement.

In terms of study weakness, this study only examines one variable which is nutritional status. In fact, other variables may affect school achievement, but are not excluded, such as learning motivation, learning anxiety, and family support. Further research is needed on the relationship between nutritional status and school achievement of elementary school students with improvements in assessing various factors.

In conclusion, there is no significant relationship between nutritional status and school achievement. Since school achievement is multifactorial, further study is very interesting to assess other factors that can affect school achievement.

\section{Acknowledgment}

We would like to thank the Principals and students of SDN Penjaringan 08 Pagi, SDN Penjaringan 10 Pagi, SDS Stella Maris, and SDS Westin for their participation.

\section{References}

1. Schleicher A. PISA 2018: insights and interpretations. OECD Publishing [internet] 2019 [cited 2021 January 18]. Available from: https://www.oecd.org/.

2. Dalyono M. Psikologi pendidikan. Jakarta: Rineka Cipta; 2009.

3. Wahyuningsih E. Hubungan status gizi dengan prestasi belajar pada anak kelas $\mathrm{V}$ SDN 01 Kadilanggon Wedi Klaten. Jurnal Involusi Kebidanan. 2014;4(8):47-59.

4. Badan Penelitian dan Pengembangan Kesehatan Kementerian Kesehatan Republik Indonesia. Laporan Nasional Riskesdas 2018. Jakarta: Badan Penelitian dan Pengembangan Kesehatan Kementerian Kesehatan Republik Indonesia; 2019. p. 154-66.

5. Asmare B, Taddele M, Berihun S, Wagnew F. Nutritional status and correlation with academic performance among primary school children, northwest Ethiopia. BMC Res Notes. 2018;11(1):805.

6. Wingfield RJ, Graziano PA, McNamara JP, Janicke DM. Is there a relationship between body mass index, fitness, and academic performance? Mixed results from students in a Southeastern United States elementary school. Curr Issues Educ. 2011;14(2):1-10.

7. Menteri Kesehatan Republik Indonesia. Peraturan Menteri Kesehatan Republik Indonesia Nomor 2 Tahun 2020 tentang Standar Antropometri Anak. Jakarta: Kementerian Kesehatan Republik Indonesia; 2020.

8. Direktorat Pembinaan Sekolah Dasar. Panduan penilaian untuk sekolah dasar (SD). Jakarta: Direktorat Pembinaan Sekolah Dasar Direktorat Jenderal Pendidikan Dasar dan Menengah Kementrian Pendidikan dan Kebudayaan; 
2016.

9. Muchlis M, Ernalia Y, Firdaus F. Hubungan status gizi dengan prestasi belajar siswa Sekolah Dasar Negeri 063 di Pesisir Sungai Siak Kecamatan Rumbai Pesisir Kota Pekanbaru. Jurnal Online Mahasiswa Bidang Kedokteran. 2015;3(1):8224.

10. Mustika PWSD. Hubungan status gizi dengan prestasi siswa di SDN 010 Pangkalan Kerinci Kabupaten Pelalawan 2017. Menara Ilmu. 2017;11(78):92-100.

11. Amany T, Sekartini R. Hubungan antara status gizi dengan prestasi belajar siswa SDN 03 Pondok Cina Depok Tahun 2015. Sari Pediatri. 2017;18(6):487-91.

12. Maku A, Mendri NK, Devianto A. Hubungan antara status gizi dengan prestasi belajar anak sekolah dasar di SDN Ngringin Depok Sleman Yogyakarta. Caring: Jurnal Keperawatan. 2018;7(1):1-8.

13. Antono SD. Perbedaan prestasi belajar antara siswa obesitas dan tidak obesitas pada siswa Sekolah Dasar di Kota Kediri. Jurnal Ilmu Kesehatan. 2017;5(2):84-90.

14. Rawung MM, Wungouw HIS, Pangemanan DHC. Hubungan status gizi dengan prestasi belajar siswa SD Katolik St Fransiskus Xaverius Kakaskasen Kota Tomohon. eBiomedik. 2020;8(1):11-8.

15. Maleke V, Umboh A, Pateda V. Hubungan status gizi dengan prestasi belajar siswa Sekolah Dasar di Kecamatan Modoinding. e-Clinic. 2015;3(3):750-3. 